\title{
The use of a diamond ranking and peer interviews to capture pupils' perspectives
}

\section{Niemi, Reetta}

2018-11-08

Niemi , R , Kumpulainen , K \& Lipponen , L 2018 , ' The use of a diamond ranking and peer interviews to capture pupils' perspectives ' , Improving Schools, vol. 21 , no. 3 , pp. 240-254 . https://doi.org/10.1177/1365480218774604

http://hdl.handle.net/10138/309990

https://doi.org/10.1177/1365480218774604

acceptedVersion

Downloaded from Helda, University of Helsinki institutional repository.

This is an electronic reprint of the original article.

This reprint may differ from the original in pagination and typographic detail.

Please cite the original version. 
Corresponding author:

Reetta Niemi,

PhD, lecturer, Viikki Teacher Training School, University of Helsinki, Finland

Research Associate, Faculty of Education, University of Johannesburg, South Africa

P.O Box 30

00014 University of Helsinki, Finland

reetta.niemi@helsinki.fi

Co-authors:

Kristiina Kumpulainen

Faculty of Educational Sciences

P.O Box 9

00014 University of Helsinki, Finland

kristiina.kumpulainen@helsinki.fi

Lasse Lipponen

Faculty of Educational Sciences

P.O Box 9

00014 University of Helsinki, Finland

lasse.lipponen@helsinki.fi 
The use of a diamond ranking activity and peer interviews to in capture ing pupils' perspectives

\begin{abstract}
In the new national core curriculum for Finnish preschool and basic education (FNBE, 2014 ), rationales for supporting pupil participation are framed by the goal of developing school communities by listening to pupils' perspectives, the social nature of teaching and learning and pupils' participatory role in planning, implementing and evaluating their own learning. Also in educational literature, listening to pupils' perspectives is seen as the first step of participation.
\end{abstract}

Framed by these rationales, this paper is based on a six-week-long participatory learning project in one 2nd second grade classroom in Finland. The research group of 8-year olds included 11 girls and 10 boys. In this study, we used diamond ranking and peer interviews as mediating tools in listening to the pupils' perspectives. In the paper, we describe how a diamond ranking activity and a peer interview worked as a tool in capturing pupils' perspectives. Two questions guided the research work: 1 . How did the diamond ranking activity and the peer interview work together as a method to improve teacher's understanding from the pupils' perspectives? 2. How did the diamond ranking activity and the peer interview work together as a method to promote pupils' participation?

In this study, the second graders were able to implement diamond ranking activity. Theis activity was used as a tool to stimulate pupils' perspectives that were then captured in peer interviews. The methods provided important information about the pupils and helped the teacher to understand their perspectives. Diamond ranking activity and peer interviews also revealed information that was not related to pedagogical practices but indicated the sense of relatedness among pupils. In this study, the process of doing peer interviews was a child-led practice, whilst the process of doing diamond ranking activity was teacher oriented. The method would have served pupils' participation better if pupils had been more involved more in the data collection.

Keywords: diamond ranking, peer interviews, teacher research, pupils' perspectives, participation

Introduction

The importance of acknowledging pupils' participation in school communities is strongly emphasised lin the new national core curriculum for Finnish preschool and basic education (FNBE, 2014), which came into effect in 2016, the importance of acknowledging pupils' participation in school communities is strongly emphasised. Pupils' participation is valued in Finnish education and the curriculum states the importance of listening to pupils' perspectives as the first form of participation. Also in educational literature it is stated, that That supporting pupils' participation should start from with listening to them is expressed in the literature (e.g. Shier, 2001; Lundy, 2007).

In terms of participation, the Finnish national core curriculum also stresses the social nature of teaching and learning. It focuses on developing pupils' skills for active, investigative, reflective and communicative learning. The core curriculum states that play, imagination and artistic elements in teaching and learning will improve pupils' conceptual and methodological knowledge and skills for critical and creative thinking. It 
also defines that each pupil must be provided with an opportunity at least once in a year to join a multidisciplinary learning module that is close to his or her own interests and provides ways to participate in the process of planning, implementing and evaluating learning (FNBE 2014, 29 ).

These elements are not new in the field of education; for decades, various studies have pointed out the importance of listening to pupils' perspectives in developing education (Nieto, 1994; Dahl, 1995; Raymond, 2001; Cook-Sather, 2002; Whitehead and Clough, 2004; Bragg, 2007) or described the social nature of teaching and learning (Wenger, 1998; Brophy, 2002; Wells, 2002; Kumpulainen \& Renshaw, 2007). There are have also been a number of studies related to pupils' participation in the school context that discuss how pupils' their participation can be enabled in school contexts (Kirby \& Woodhead, 2003; Whitehead \& Clough, 2004; Maitles \& Deuchar, 2006; Susinos \& Haya, 2014; Niemi, Kumpulainen, Lipponen \& Hilppö, 2015; Niemi, Kumpulainen \& Lipponen, 2015a; 2015b).

However, on both a national and international level there is a lack offew and a need for studies that have provided examples of how these three goals could be enacted in the everyday life of classrooms, on both national and international levels. Rather, there are studies that show that pupils' options for participating, expressing their perspectives and taking part in decision making in the classroom are often organised around specific projects, which are, in many cases, are 'add-on' practices in classroom life (Malone \& Hartung 2010, 32).

It is well-known that authorizing pupils' perspectives can directly improve educational practices. When teachers listen to and learn from pupils, they can begin to see the world from their perspectives (Dahl, 1995; Cook-Sather, 2002). One way to meet this goal has been to apply photo-elicitation to capture pupils' perspectives on their lives. Photo-elicitation has often been used to enhance informants' engagement in interviews, challenge participants, provide nuances, trigger memories and lead to new perspectives and explanations (Lapenta, 2011). The use of photographs has been identified as particularly helpful for pupils to document and communicate their perspectives on what constitutes a meaningful classroom experience (Caine, 2010; Cook \& Hess, 2007; Smith, Duncan, \& Marshall, 2005). The use ofUsing photographs has also been reported to as helping young people to discuss their experiences instead of merely commenting in abstract terms (Cook \& Hess, 2007).

DThe diamond ranking activity, also known as 'diamond 9', is one form of photo-elicitation. In the literature, a diamond ranking activity has been seen as a participatory research method among pupils (Woolner et al., 2010, 2012, 2014; Clark, 2012; Clark et al., 2013; O’Kane, 2013). Our intervention of using a diamond ranking activity and peer interviews took place at the end of a six-week long multidisciplinary learning project that was implemented in the classroom of the teacher-researcher in Finland, who is also the first writer author of this article, in Finland. In this paper, we explore how a diamond ranking aactivity and peer interviews worked together as a method that provided pupils' opportunities to express their perspectives from the project and help teachers to understand pupils better.

Two questions guide our research work:

1. How did diamond ranking and the peer interview work together as a method to improve teacher's understanding from the pupils' perspectives?

2. How did diamond ranking and peer interviews work together as a method to promote pupils' participation?

In the next sections that follow, we focus on clarifying the concept of participation in a classroom practices. Next, we describe the process of collecting data through the diamond ranking activity and peer interviews 
that were used in this research initiative. In the results, we deal with our research questions separately and in the conclusion, we summarise this project and suggest new directions for further studies.

\section{Pupils' participation in classroom practices}

As participation practice has grown, so has the number of guides and models to support practice (Hie. Hart, 1992; Treseder, 1997; Shier, 2001; Reddy \& Ratna, 2002; Lundy, 2007; Landsdown, 2001; 2010). At the same time, the concept of participation carries multiple meanings. In the literature, the concept refers generally refers to the process of recognising pupils' participation and views in decision-making that affects pupils' lives and the life of the community in which they live (Hart, 1992; 2008; Shier, 2001; Sinclair, 2004; Lundy, 2007; Landsdown, 2010).

Gerison Landsdown (2010) has pointed out the importance of finding key indicators to evaluate evidence of the cultural climate in which the right of children (the pupils in this study) to be heard and taken seriously is established. She also thinks that it is necessary to be able to measure the extent, quality and impact of actual participation in which pupils are engaged. From her point of view, pupils should be able to participate in evaluating their participation. Landsdown (2010) has classified pupils' participation at into three levels: (1) Consultative participation is a level in which adults seek pupils' views in order to build knowledge together. The actions are adult led and managed and pupils are not joiningdo not participate in the decision-making. (2) Collaborative participation provides a greater degree of partnership between adults and pupils. At this level, pupils can be involved in designing and undertaking different kinda range of of actions, like such as undertaking research, being representations representatives on boards and comities committees, and so on. Collaborative participation provides an opportunity for shared decision making with adults. (3) Child-led participation takes place when pupils are afforded the space and opportunity to identify issues of concern, initiative activities and advocate for themselves. The role of adults is to act as facilitators to enable pupils to pursue their own objectives through the provision of information, advice and support. In this study we are usinghave used these categories in to evaluateing pupils' participation in the research process.

In the literature, it is common that examples related to pupils' participation in schools are organised around specific projects (e.g. Malone \& Hartung 2010, 32) instead of focusing on lessons and teaching practices. Berit Bae (2009) also points out that the phenomenon oa of participation is too often reduced to dealing with decision making and pupils' role in that. When we talk about pupils' participation, we should always remember how that pupils' participation also exists in everyday communication.

Our insight of on participation follows the four aspects defined by Tomi Kiilakoski, Anu Gretschel and Elina Nivala (2012):. (1) Participation is a relational phenomenon. (2) It involves having a formally and informally recognized position as an agent. (3) It should manifest itself in actions,; sayings, doings and relating's and (4) it should also produce a feeling of participation. Based on these perspectives, in this study, we have chosen to look at pupils' experiences on of learning activities from three different angles: a) pupils' experiences of autonomy and affecting on one's own learning, b) pupils' experiences on the sense of relatedness in communication and play and c) pupils' experiences of their competenc es in sayings and doings.

\section{Study Methodology of the study}

As John Loughran (2002) has stateds, if change in the classrooms is desired, knowledge that is useful, informative and valuable to both the educational community at large and teachers in their everyday 
classroom practices should be produced. Loughran (2002) and Mitchell (2002) regard teacher-research as a research methodology that provides knowledge that could also be useful to teachers.

This study is based on teacher-research and relies methodologically on educational action research (Kemmis, 2006; Nofke \& Somekh, 2013). Teacher-research was launched by Lawrence Stenhouse in 1975. From Stenhouse's point of view, a theory of education is an articulation of teachers' shared practical understanding of how they make their practice in classrooms more educational through concrete situated action (Elliott, 2013). Teacher-researchers work in their school communities, examine their own assumptions and develop local knowledge through research methods. Often these methods draw on biographical, autobiographical and narrative forms of data collection and analysis. In many versions of the teacher research as in this study, the work is done to improve social justice of in classrooms and to ensure educational opportunity, access and equity for all pupils (Cochran-Smith \& Lytle, 2013).

We hold that teacher-research involves discovering new ways to gain information about pupils' perspectives of classroom practices. It is participatory by nature; its goal is to work with pupils and see them as co-researchers (Niemi et al., 2010; Niemi, Kumpulainen, Lipponen \& Hilppö, 2014; Niemi, Kumpulainen \& Lipponen, 2015a; 2015b). In this study, we used diamond ranking activity and peer interviews as a tools to listen to the pupils' perspectives. Diamond ranking was also originally used as a thinking skill tool and it was valued for extracting constructs and facilitating discussion (Rockett \& Percival, 2002). In our study, the purpose of diamond ranking was to facilitate pupils' perspectives that we wanted to capture through peer interviews. Peer interviews can also be considered as a validation tool because the meanings behind pupils' choices in photo elicitation sometimes carry a very quite different meaning than from the one expected at the outset (e.g. Crogham et al., 2008; Niemi, Kumpulainen, Lipponen \& Hilppö, 2014).

In this study, the teacher-researcher, who is also the first author of this paper, implemented the learning project together with her pupils. She also collected the data with pupils and analysed the data. However, the paper was written, and interpretations were made in co-operation with all authors. Therefore, Mitchell's (2002) ideas of doing teacher-research in a collaborative relationship with a teacher-researcher and academic researchers have been implemented in the study.

Collecting data in the classroom community

The study took place in a suburban elementary school district in the city of Helsinki, Finland. A total of 21Twenty-one pupils ( 11 girls, 10 boys) and one teacher participated in the study. The data collection took place between September and November 2016 and November 2016. At the time of the research, the pupils were in the second grade (approximately 8 years old). One-third of the pupils had a multicultural background and four of them did not speak Finnish as a first language. The data consisted of 21 diamond 9s and 20 peer interviews. The data also included the teacher-researcher's reflection on the workability of the method.

DThe diamond rankingg activity, also known as 'diamond 9', is one form of photo-elicitation. It has beenwas developed and used by a British team to engage young people in the research process (Woolner et al., 2010, 2012, 2014; Clark, 2012; Clark et al., 2013). The method involves a subset of nine photographs. 
Participants, working in pairs or threes, cut out these pictures and stick them onto a piece of paper in a diamond shape, ranking them by position so that the preferred picture is at the top and the one most disliked is at the bottom. Participants also annotate the diamond with comments and explanations (Woolner et al., 2010, 2012, 2014; Clark, 2012; Clark et al., 2013).

According to Clark (2012; 2013), diamond ranking is valuable for extracting constructs and facilitating talk. When ranking items whether they are statements, objects or images, the participants are required to make obvious the overarching relationships by which they organise knowledge. That makes their understanding available for analysis and comparison (Clark, 2012; Clark et al., 2013). In the classroom context, diamond ranking has been used as a tool to elicit pupils' perspectives because it is deemed as motivating for pupils.; lit has also been found to increase the response rate and the authenticity of their answers (Hopkins, 2008; Baumfield et al., 2013).

The data derive from a multidisciplinary learning module called 'From a seed to a product' described in Table 1. The project lasted for 50 lessons that took place forspread over five weeks. In the project, the pupils investigated plants cultivated in gardens and fields in Finland. Each pupil was able to choose one plant to investigate more carefully. Pupils also investigated the living conditions of plants in a classroom. At the end of the project, the class created two narratives called 'From a seed to a product'. The first narrative was a shared visual narrative including art and handcrafts depicting the route of wheat from fields to storesshops. The second narrative was an individually written narrative from the plant that the pupil had investigated. At the end of the project, a harvesting party was held in the classroom and pupils baked sweet buns from the wheat for the party.

During the learning project, the teacher-researcher had taken pictures of each learning activity. At the end of the project, the teacher-researcher created a Power-Point presentation of nine slides that included photographs of from different several project activities. The slides depicted: 1 . investigative learning practices, 2. a trip to a garden and choosing a plant, 3. planting peas and investigating the living conditions of plants, 4 . searching the Internet for information about the plant, 5 . writing a narrative, 6 . joining feedback discussions, 7. writing in a notebook, 8. creating a visual narrative and. 9. baking sweet buns.

When viewing the photographs, the teacher-researcher and the pupils discussed their contents and whatthe other practices related to the project that belong to the category. After reviewing the slides, the teacher-researcher informed the pupils about diamond ranking and showed an example of a diamond 9 into which she had written the meaning of each row. The teacher showed that she had printed handouts of the slides. She also explained that a slide of the most positive experience should be placed on the first row, while the slides of the next two most positive experiences should be placed on the second row. On the third row, pupils were supposed to place the slides of experiences that were of medium interest or value to them. On the fourth row, pupils were supposed toshould place two slides of the experiences that were second to least positive for them. Finally, on the fifth row, pupils were asked to place one slide of the experience that was the least positive to them and that needed the most improvement. The pupils then followed the instructions and cut the slides from the handouts and glued them into to a diamond 9 format. Figure 1 shows the premade model of a diamond 9 and how it was used. 
Figure 1 Students constructing diamond 9 forms

After diamond ranking, the pupils planned interview questions. In a shared discussion, they suggested five questions: 1 . What were your three first choices? 2. What were your reasons for ranking the first three slides? 3. What were your last three choices? 4 . What were your reasons for ranking the last three slides? 5. How can teachers improve these activities? After that, the pupils completed peer interviews in groups. There were three pupils in each group. One pupil at a time was an the interviewer, one was the interviewed interviewee and one videotaped the interview with an iPad.

\section{Data analysis}

At the beginning of the analysis, the teacher-researcher scored diamonds so that each activity received the correct number of points; the fewer the points received, the more appreciated it was. Thus, she gained a general view of pupils' experiences of which activities were the most liked, which were considered as medium experiences, and which were perceived as the least positive.

At During the next stage of the analysis, the teacher-researcher listened to pupils' peer interviews, which varied from a minute to 3-4 minutes. The teacher-researcher transcribed the interviews and classified findings. The findings were classified and namedin to three categories: a) pupils' experiences of autonomy and affecting on one's own learning, b) pupils' experiences on the sense of relatedness in communication and play and c) pupils' experiences of their competences in sayings and doings. At the end of the analysis, she compared the findings with her pre-assumptions of each pupil. The pre-assumptions were based on the teacher-researcher's observations and knowledge about each pupil that she had gained, because since she had taught the pupils since they were the first graders. After transcribing the interviews, the teacherresearcher recorded how her understanding either strengthened or changed because of listening to the each pupil's' perspective. In the results, we illustrate our findings and the teacher's reflections have been illustrated with interview extracts.

In the first section of the results, we discuss from the pupils' perspectives and how these results from the pupils' perspectives and how they helped the teacher-researcher to get to know her pupils better. Secondly, we discuss the workability of the method according Gerison Landsdown's (2010) classification:; on which level of participation the pupils could participate in the process of developing classroom practices and examine the potential of these methods to support pupils' participation.

Results

The pupils' perspectives in enlightening the teacher's understanding of her pupils 
The three most appreciated practices of the learning project were: baking sweet buns, creating a visual narrative and planting peas and investigating the living conditions of those peas. These findings support previously well-known results: practices requiring active participation such as scientific investigations, performances, acting, painting and school trips are considered important by many primary school pupils (Hopkins, 2008, 2010; Niemi, Kumpulainen, Lipponen \& Hilppö, 2014; Niemi, Kumpulainen \& Lipponen, 2015a; 2015b). In this study pupils also brought up that they had experienced autonomy, the sense of relatedness and / or competences in those practices.

The medium experiences were the trip to the garden to choose a plant, joining feedback discussions and writing a narrative. The three least positive experiences were writing in a notebook, searching the Internet for information about the plant and investigative learning activities. In pupils' arguments, it was obvious that the pupils had experienced a lack of autonomy, the sense of relatedness in communication and / or competences in those practices.

In the interviews the pupils argued that their experiences of autonomy and affecting on one's own learning as follows:

In my opinion, writing a story and planting a pea were the best activities, because I was able to decide myself what to do and how to do it.

I didn't like those investigative practices like investigating soil. It was boring that only a few of us could do those tests and rest of us were only watching. I think it would have been nice if we all had had a role.

Quotes that expressed pupils' experiences on the sense of relatedness in communication and play were expressed in the interviews as following way:

I liked to bake sweet buns and do art stuff because I was able to do that together with my classmates.

Joining feedback discussions was nice because I was able to tell others what I had done. I also learned from others' work.

In the interviews pupils expressed their experiences of their competences in sayings and doings quite strictly.

Writing in the notebook was difficult so I didn't like it.

It couldn't search for knowledge from Internet. It was too difficult.

Some of the arguments also related to two different categories. For example, the next illustration describes how a pupil had felt both a lack of autonomy and relatedness.

The practice I didn't like was art. I didn't like that I wasn't able to do my own work. The other members of my group didn't listen to me.

In the classroom, there are fFour of the pupils in the classroom had awhose mother tongue that is not Finnish. The teacher-researcher had expected that among those pupils writing a narrative and searching for 
knowledge from the Internet there would be those who would consider the task unpleasant, because from the teacher's perspective, these practices demanded more effort from those pupils than from Finnishspeaking pupils. However, two of these pupils, for whom writing was difficult from the teacher's perspective, had ranked this practice as the second most positive practice. They reasoned for their choice that in that activity they had felt autonomy. This allowed the teacher-researcher to see these pupils from a different perspective. For example, in this learning project, the teacher-researcher had had sincerely questions before assigning the writing of narratives, whether she should have given those pupils easier tasks. After seeing the diamond ranking and listening to the peer interviews she learned that she does not need to be afraid of challenging these pupils in tasks that demand writing, but she should be aware of the importance of the pupils' need for a sense of autonomy.

In one pupil's case, the negative experiences toward writing revealed in the diamond ranking activity and peer interviews gave the teacher-researcher an opportunity to discuss these experiences with the pupil and the parents. For example, in this case the teacher found out that completing writing tasks at home demanded a lot of work both from the pupils and the parents. When that came up, in a shared discussion with the child, the parents and the teacher, they found a way to support that pupil's writing so that the child received the necessary support during a the school day, and homework were was something the child was able to manage without help.

The teacher-researcher was faced with more surprises dealing with the pupils' experiences of joining feedback discussions. In this classroom, there were a few pupils who only rarely joined classroom discussions, performed in the plays or showed any kinds of interest in being in a the spotlight in front of others. These pupils also often needed the teacher's support in expressing themselves in drama lessons. In the learning project, there were two sessions in which each pupil presented his or her own work. In one of those sessions, reading the narrative aloud was too exciting for one pupil. However, joining feedback discussions was ranked as the second to most positive practice and it seemed that it was important for those pupils to receive recognition from their peers for their work.

The peer interviews also revealed that there were some pupils who supported their two least favourite choices related to the lack of recognition in his/her study group and their choices had little to do with classroom practices. That information made the teacher-researcher consider these pupils' role in a classroom community more carefully. The teacher-researcher reflected on whether those experiences were launched because of bullying or were experiences based on a one-time previous quarrel; perhaps those pupils were not happy because others did not accept their opinions.

By the time of the study, the teacher-researcher had already taught been teaching her classroom for ten months and she thought she knew her pupils. Nevertheless, the diamond ranking activity together withand peer interviews revealed that she had had the wrongmade incorrect assumptions from about some pupils. In this study, diamond ranking activity and peer interviews gave the pupils possibilities an opportunity to express their experiences and gave the teacher a tool new way to get to know her pupils in a new way.

The workability of diamond ranking and peer interviews in promoting pupils' participation 
In this study, we followed the previous models of performing undertaking diamond ranking (e.g. Woolner, 2010, 2012, 2014; Clark, 2012; Clark et al., 2013): the teacher-researcher took and elicited the photographs used in the PowerPoint slides. When implementing diamond ranking in a classroom, it only took 45 minutes to look at the PowerPoint presentation, discuss the slides, cut up the handouts and glue the slides into boxes of diamond 9s into boxes.

Dean (2007) and Moss et al. (2007) claim that visual approaches encourage diverse modes of participation, because pupils do not have to rely solely on written or spoken words. In this study, every pupil in the classroom could complete this activity independently. However, we consider this part of the study represents consultative participation (see Landsdown, 2010) in which a teacher-researcher seek children's views in order to build knowledge. The actions were teacher led and managed and children were did not joining in the decision-making; what pictures to take on in lessons or what pictures to choose to PowerPoint presentation. We also learnt that the form of the diamond ranking activity expects presumes that participants to will like some practices and possibly dislike some others. For example, in this these data, one pupil said that she liked all the practices and she did not know what to choose as the last three choices.

Diamond ranking activity would have increased pupils' participation to the level of collaborative participation (see Landsdown 2010) if they had had a chance to collaborate more with their teacher in taking photos, making decisions and if they had had an option to plan the form of the pictures instead of placing them to a ready-made form. Furthermore, if the pupils had had a chance to use technology suitable for this age group, such as tablets, in choosing pictures and ranking them, the activity would have had a higher level of participation. In teacher-research, both the strength and weakness is are affected by the fact that the data collection is collected with the tools provided by the schools. Thus, when the diamond activity had been completed by using paper handouts and glue sticks, one can say, that the method could be transferred to other contexts, as it did not depend on the a school's' financial resources and whether they ity could afford to buy tablets for all pupils.

In participatory projects, pupils must always have an the option not to participate or to choose their level of participation how they want to participate (Sinclair, 2004; Roberts, 2008). In this classroom, 21 out ofall 21 pupils participated in both interviewing others and video recording an interview, and 20 out of 21 pupils were interviewed by others. Figure 2 shows how this practice was implemented. In this research, there was one child who withdrew from the interview process. As Roberts (2008) states, it is important, that pupils know that they can withdraw from research and that their lack of participation will not be held against them.

Figure 2. Pupils conducting peer interviews.

In an interview situationDuring interviews, pupils had diamond 9s with them and all the questions related to the diamond ranking task. The strength of this method was that pupils participated in the process of planning the research questions. In addition, pupils had recognised roles in conducting the interviews and the teacher-researcher's absence from the interview situations gave pupils more freedom in to expressing themselves. We consider that creating research questions represents the level of collaborative participation 
(see Landsdown 2010), because pupils were involved in designing their own questions and that part of the study provided an opportunity for shared decision making with the teacher. From our perspective, peer interviews supported Child-led participation (see Landsdown 2010) because the pupils were afforded the space and opportunity to identify issues of concern, initiative activities and advocate for themselves.

For example, in some interviews pupils had taken models from the news and they began their interview as follows:

- $\quad$ Good afternoon Miss Clark. I have some questions for you related to your diamond. (...)

- Hello everybody. My name is Owen and today I am going to interview Will about his diamond. (Will waves his hand to the camera.)

Even though there was no control of the teacher-researcher exercised no control in conducting the interviews, the pupils took seriously their roles seriously and none of the interviews were spoiled by clowning or misbehaviour. However, in one- third of the interviews, if an interviewed pupil did not give reasons for his/her choices, the interviewer asked the next question without asking the pupils to give more specific reasons.

- What was your reason for ranking the first three slides?

- $\quad$ Because I liked it.

- What was your reason for ranking the last three slides?

- $\quad$ Because I didn't like it.

- How should teachers improve those practices?

- I don't know.

In an interview situation, pupils had very different skills in either working as an interviewer or in defending the reasons for their choices. Some pupils had many reasons for their choices and they argued them carefully.

The best practices were handicraft, growing one's own plant and a field trip. First of all, handicraft is very important to me. That is the reason for that. I liked growing my own plant, because I have always wanted to have my own plant. I was so happy that I was able to take care of the plant and I was able to do everything by myself. Nobody didn't interfere me. I liked the field trip. First of all, I just like doing trips. I also liked this trip, because I was able to choose my plant myself.

Interestingly, for some pupils, the role of an interviewer role was challenging, because they had problems in listening to other pupils' answers. One interview went as follows:

- What was your reason for ranking the first three slides?

- I liked to bake because then I could eat sweet buns afterwards.

- What was your reason for ranking the last three slides? 
- I didn't like to search for the origins of food?

- What?

- I mean those practices, when...

- $\quad$ Oh yeah, I understand. How should teachers improve those practices?

- $\quad$ I think that teachers should show more...

- Yeah, yeah, I understand.

The main problem in the interviews was the lack of suggestions for how teachers should improve their practices. There were oOnly a few pupils that replied to that question in the interviews; thus, the teacherresearcher brought this question back to the pupils. In the classroom, pupils and the teacher-researcher had a joint discussion about the practices that were ranked as the least- positive practices. Then the pupils talked about their improvement ideas in pairs and these ideas were written on the PowerPoint slides and the slides were printed and placed on the wall of the classroom. Pupils' suggestions were for example as follows:

- All pupils should be able to investigate

- All pupils should also be able to touch the investigation tools of investigation.

- Pupils should receive information inabout evaluating website content.

- Pupils should write up the information found byon a computer instead of writing in a note books by hand.

- Pupils should be able to either draw or write in their notebooks.

Even though one-third of the pupils had problems in defending their choices and most of the pupils were not able to give suggestions about how classroom practices could be improved, pupils should still be able to practice these issues. We think this 'failure' shows that full participation requires skills: students need skills to express their own opinions, to argue and present their own opinions, to make constructive suggestions and even skills to learn to listen to other's' opinions. Those skills are needed infor affecting influencing their own lives and the life of the community in which they live. Those are the skills that are needed in to achieveing the goals of participation set in by the Finnish national core curriculum (FNBE, 2014). In this study diamond ranking and peer interviews gave pupils a way to practice those skills.

\section{Conclusion}

The new national core curriculum for Finnish preschool and basic education (FNBE, 2014) strongly emphasises the importance of acknowledging pupils' perspectives as the first form of participation in school communities. It also emphasises the social nature of teaching and learning and children's participatory role in planning, implementing and evaluating their own learning.

In this paper, we have described how a six-week-long multidisciplinary learning project was implemented in one classroom (the 2nd second grade) in Finland. We also discussed, how diamond ranking and peer interviews worked in promoting pupils' opportunities to express their perceptions about the project to help the teacher to develop and improve classroom practices and to get to know the pupils better. Two questions guided our research work: 1 . How did diamond ranking and the peer interview work together as 
a method to improve teacher's understanding from pupils' perspectives of participation? 2. How did diamond ranking and peer interviews work together as a method to promote pupils' participation?

In this study, teacher-research provided the methodological starting point (e.g. Rudduck \& Hopkins, 1985; Cochran \& Smith-Lytle, 2013; Elliott, 2013). In this study, diamond ranking activity and peer interviews gave the pupils possibilities opportunities to express their experiences and gave the teacher a tool to get to know her pupils in a new way. In this study, the teacher-researcher used diamond ranking and peer interviews techniques to provide the pupils with a mediating tool to express their perspectives. In our study, the meaning of diamond ranking was to facilitate pupils' perspectives, which were later captured through peer interviews. Peer interviews were also considered as to be a validation tool because the meanings behind pupils' choices in photo elicitation sometimes carries a very quite different meaning than one would have expected from the outset (e.g. Crogham et al., 2008; Niemi, Kumpulainen, Lipponen \& Hilppö, 2014).

In general, the results of our study revealed results that are similar to the results of previous research; practices requiring active participation such as scientific investigations, performances, acting, painting and school trips are considered important by many primary school pupils (Hopkins, 2008, 2010; Niemi, Kumpulainen, Lipponen \& Hilppö, 2014; Niemi, Kumpulainen \& Lipponen, 2015a; 2015b). In this study, the most appreciated practices had supported pupils' experiences of autonomy, sense of relatedness in communication and play among other pupils and competences in sayings and doings.

In teacher-research, one goal is to improve social justice of in classrooms and to ensure educational opportunity, access and equity for all pupils (Cochran-Smith \& Lytle, 2013). By the time of the study, the teacher-researcher had already been teachingtaught her classroom for ten months and she thought she knew her pupils. Nevertheless, the diamond ranking activity together witandh peer interviews revealed that she had had the wrong assumptions from about some pupils. In this study, the teacher-researcher was even able to find new ways of to supporting her pupils.

According to O'Kane (2008), in methodological considerations for good practices, it is important to evaluate whether pupils understood understand the meaning of the work. In this study, we learned that all pupils understood the reason for doing diamond ranking and they were able to perform undertake diamond ranking independently. This research also showed produced results similar results to O'Kane's (2008) findings: participatory techniques (diamond ranking activity) dides not cause extra work for pupils, it dides not increase the amount of work for the teacher-researcher, and it required only paper and glue sticks as materials. Therefore, we see that this practice has the potential to be transferred to other contexts because it did does not require an extraordinary amount of effort or financial resources.

In the research literature, the diamond ranking activity has been seen as a participatory research method (O'Kane, 2008; Woolner et al., 2010; 2012;2014). In this study, we learned that the diamond ranking activity has offers shortcuts when it comes to participation. The ready-made form reduced pupils' chances opportunity to express their experiences and they could not participate in designing the tool for data collection. Furthermore, pupils did not have the option to take or choose pictures freely because the teacher-researcher made the photo elicitation. This part of the study was mainly teacher oriented and pupils' role stayed on at the level of consultative participation ( see, Landsdown 2010). 
In this study, the process of planning the interview questions supported collaborative participation (see Landsdown, 2010). The pupils completed peer interviews without their teacher's presence. That part of the study made it possible for the pupils to participate in designing research questions and to work as coresearchers (e.g. Raymond, 2001; Alderson, 2008). In peer interviews, the pupils took seriously their roles seriously. Our interpretation is that these sequences supported child-led participation (see Landsdown, 2010).

The level of pupils' responses in the interviews varied. In two- thirds of the interviews, the pupils could give reasons for their choices but in one-third of the interviews, there were problems in either reasoning presented for choices or listening to one another's replies. It was also difficult for pupils to give suggestions on how to improve teaching practices. However, the most important point was that the interviews gave provided important information about individual pupils and helped the teacher-researcher to understand these pupils' experiences from a new perspective. Eventually, she could analyse her own practice incorporating this new knowledge. Diamond ranking and peer interviews also revealed information that was not related to pedagogical practices but was pertinent to pupils' social interaction.

As Max van Manen (2002) has put it, teachers are often sincere but no matter what their good intentions are, what seems ultimately seems more important is how pupils experience them and their teaching practices. That is why there is a need for the development of a discipline that can be attentive to the way pupils experience their lives in classrooms. He also calls for discussion of the normativity of distinguishing between what is appropriate and what is less appropriate for pupils and what are appropriate ways of teaching and giving providing assistance to pupils.

The method used in this study is not problematic. If pupils' opinion is only asked for, but not put it in action, it only represents a veryonly tokenistic practice. In this study, we did not have a further data to express explain if the pupils had experienced that their ideas were taken seriously. For further future studies, we see that this as an important development area. We also think that in this method, there is a risk that pupils can misunderstand their role wrong and in peer interviews focus on criticizing each other. In that case, the method could be used as a tool for bullying . In this study, there was one example in which one a pupil's choices were argued with, because through of negative experiences of other pupils. By tThis meansing, that the method needs to be dealt with tactfullyness from by a teacher to guide pupils to focus on practices instead of other pupils. One pitfall of this method relates also to a the teacher's power-relationship. There is no guarantee that pupils will say all negative aspects or colour their experiences more positive that they actually are. These issues must be seen as ethical issues and they have to be considered carefully. Even though our study was not problematic, we still believe that methods, such as diamond ranking activity and peer interviews, should be seen as useful tools in pupils' educational process in which they are provided with skills on how to manage their lives and feel a sense of participation and agency.

\section{References}

Alderson, P. (2008). Children as Researchers. Participation Rights and Research Methods. in P. Christensen \& A James (Ed.), Research with Children. Perspectives and Practices (pp. 276-290). Oxon: Routledge.

Bae, B. (2009). Children's right to participate - challenges in everyday interactions. European Early Childhood Education Research Journal 17 (3), 391-406.

Baumfield, V., Hall, E., \& Wall, K. (2013). Action Research in Education. London: Sage. 
Brophy, J. (2002). (Ed.) Social Constructivist Teaching: Affordances and Constraints. Vol 9. Bingley: Emerald Group Publishing Limited.

Caine, V. (2010). Visualizing community: understanding narrative inquiry as action research. Educational Action Research 18(4), 481-496.

Clark, J. (2012). Using diamond ranking as visual cues to engage young people in the research process. Qualitative Research Journal 12(2), 222-237.

Clark, J., Laing, K., Tiplady, L. et al. (2013). Making Connections: Theory and Practice of Using Visual Methods to Aid Participation in Research. Newcastle upon Tyne: Research Centre for Learning and Teaching, Newcastle University.

Cochran-Smith, M. \& Lutle, S-L. (2013). Teacher Research as Stance. in S.E. Noffke \& B. Somekh (Ed.), The SAGE Handbook of Educational Action Research (pp. 39-49). London; SAGE.

Cook-Sather, A. (2002). Authorizing Students' Perspectives: Toward Trust, Dialogue, and Change in Education. Educational Researcher 31 (4), 3-14.

Cook, T. \& Hess, E. (2007). What the camera sees and from whose perspective: fun methodologies for engaging children in enlightening adults. Childhood 14(1), 29-45.

Croghan, R., Griffin, J., Hunter, J. et al. (2008) Young people's constructions of self: notes on the use and analysis of the photo-elicitation methods. International Journal of Social Research Methodology 11(4), 345356.

Dahl, K. (1995). Challenges in Understanding the Learner's Perspective. Theory into Practice 34 (2), 124130.

Dean, C. (2007). Young travellers and the Children's Fund: some practical notes on an experimental image based research project. Journal of Research in Special Educational Needs 7(1): 16-22.

Elliott, J. (2013). Building Educational Theory through Action Research. in S.E. Noffke \& B. Somekh (Ed.), The SAGE Handbook of Educational Action Research. (pp. 28-38). London: SAGE.

Hart, R.A. (1992). Children's Participation, from Tokenism to Citizenship. UNICEF: Florence. Retrieved from http://www.unicef-irc.org/publications/pdf/childrens_participation.pdf 
Hart, R. (2008). Stepping Back from 'The Ladder': Reflections on a Model of Participatory Work with Children. in A. Reid, B.B. Jensen, J. Nikel \& V. Simovska (Ed.), Participation and Learning. Perspectives on Education and the Environment, Health and Sustainability. (pp. 19-31) Springer.

Hopkins, E. (2008). Classroom conditions to secure enjoyment and achievement: the pupils' voice. Listening to the voice of Every Child Matters. Education 3-13 36(4), 393-401.

Hopkins, E. (2010). Classroom conditions for effective learning: hearing the voice of Key Stage 3 pupils. Improving Schools 13(1), 39-53.

Kiilakoski, T., Gretschel, A. \& Nivala, E. (2012). Osallisuus, kansalaisuus ja hyvinvointi. In A. Gretschel \& T. Kiilakoski (Ed.), Demokratiaoppitunti. Lasten ja nuorten kunta 2000-luvun alussa (pp. 11-19). Helsinki: Nuorisotutkimusverkosto / Nuorisotutkimusseuran julkaisuja 118.

Kumpulainen, K., \& Renshaw, P. (2007). Cultures of Learning. International Journal of Educational Research, 46, 109-115.

Kirby, P. \& Woodhead, M. (2003). Children's participation in society. in H. Montgomery, R. Burr \& M. Woodhead (Ed.), Changing Childhoods. Local and global pp. 233-272) Chichester: Open University Press.

Landsdown, G. (2001). Promoting children's participation in democratic decision-making. Unisef. Retrieved from https://www.unicef-irc.org/publications/pdf/insight6.pdf

Landsdown, G. (2010). The realisation of children's participation rights: critical reflections. In B. PerceySmith \& N. Thomas (Ed.), A Handbook of Children and Young People's Participation. Perspectives from Theory and Practice (pp. 11-23). Oxon: Routledge.

Lapenta, F. (2011). Some Theoretical and Methodological Views on Photo-elicitation. In E. Margolis and L. Pauwels (Ed.),The Sage Handbook of Visual Research Methods (pp. 201-213). London: Sage.

Loughran, J. (2002). Researching Teaching for Understanding. in J. Loughran (Ed.), Researching Teaching: Methodologies and Practices for Understanding Pedagogy (pp. 1-9). London: Routledge.

Lundy, L. (2007). Voice' is not enough: conceptualising Article 12 of the United Nations

Convention on the Rights of the Child. British Educational Research Journal

$33(6), 927-942$.

Maitles, H. \& Deuchar, R. (2006). We don't live democracy, we live it. Consulting pupil voice in Scottish schools. Education, citizenship and social justice 1(3), 249-266.

Malone, K. \& Hartung, C. (2010). Challenges of participatory practices with children. in B. Percey-Smith \& N. Thomas (Ed.) A Handbook of Children and Young People's Participation. Perspectives from Theory and Practice (pp. 24-38). Oxon: Routledge. 
Mitchell, I. (2002). Bridging the Gulf Between Research and Practice. in J. Loughran (Ed.) Researching Teaching: Methodologies and Practices for Understanding Pedagogy (pp. 44-64). London: Routledge.

Moss, J., Deppler, J., Astley, J. et al. (2007). Student researchers in the middle: using visual images to make sense of inclusive education. Journal of Research in Special Educational Needs 7(1): 46-54.

The national core curriculum for Finnish preschool and basic education (2014). Retrieved from: http://www.oph.fi/ops2016/perusteet

Niemi, R., Kumpulainen, K. \& Lipponen, L. (2015a). Pupils' documentation enlightening teachers' practical theory and pedagogical actions. Educational Action Research 23 (4), 599-614.

Niemi, R., Kumpulainen, K. \& Lipponen, L. (2015b). Pupils as active participants: Diamond ranking as a tool to investigate pupils' experiences of classroom practices. European Educational Research Journal.

$10.1177 / 1474904115571797$

Niemi, R., Kumpulainen, K. \& Lipponen, L. (2016). Pupils' Participation in the Finnish Classroom: turning the UN Convention on the Rights of the Child into pedagogical practices. in J. Gillet-Swan \& V Coppock (Ed.), Children's Rights, Educational Research and the UNCRC: past, present and future (pp. 81-100). Oxford: Symposium Books.

Niemi, R., Kumpulainen, K. \& Lipponen, L.\& Hilppö J. (2015). Pupils' perspectives on the lived pedagogy of the classroom. Education 3-13 43 (6), 681-697.

Noffke, S.E., \& Somekh, B. (2013.) (Ed.), The SAGE Handbook of Educational Action Research. London; SAGE.

Nieto, S. (1994). Lessons from Students on Creating Change to Dream. Harvard Educational Review 64 (4), 392-426.

O'Kane, C (2008). The Development of Participatory Techniques. Facilitating Children's Views about Decision Which Affect Them. in P. Christensen \& A James (Ed.), Research with Children. Perspectives and Practices. Oxon: Routledge, 125-155.

Prout, A. (2000). Children's participation: control and self-realisation in British late modernity. Children \& Society 14, 304-315.

Raymond, L. (2001). Student involvement in school improvement: from data source to significant voice. Forum 43(2), 58-61.

Reddy, N. and Ratna, K. (2002) A Journey in Children's Participation. Vimanapura: The Concerned for Working Children. Retrieved from https://resourcecentre.savethechildren.net/sites/default/files/documents/2625.pdf 
Roberts, H. (2008). Listening to Children: and Hearing Them. in P. Christensen \& A James (Ed.), Research with Children. Perspectives and Practices (pp. 260-275). Oxon: Routledge.

Rockett, M. \& Percival, S. (2002). Thinking for learning. Stafford: Network Educational Press.

Rudduck, J., and D. Hopkins. 1985. Research as a Basis for Teaching. Oxford: Heinemann.

Shier, H. (2001) Pathways to Participation: Openings, Opportunities and Obligations. A New Model for Enhancing Children's Participation in Decision-making, in line with Article 12.1 of the United Nations Convention of the Right of the Child. Children and Society 15,107-117.

Sinclair, R. (2004). Participation in Practice: Making it Meaningful, Effective and Sustainable. Children \& Society $18,106-118$.

Smith A, Duncan, J. \& Marshall, K. (2005). Children's perspective on their learning: exploring methods. Early Child Development and Care 175(6), 473-488.

Susinos, T. \& Haya, I. (2014). Developing student voice and participatory pedagogy: a case study in a Spanish primary school. Cambridge Journal of Education 44 (3), 385-399.

Treseder P. (1997). Empowering Children and Young People: Training Manual. Save the Children and Children's Rights Office: London.

van Manen, M. (2002). The Language of Pedagogy and the Primacy of Student Experience. in J. Loughran (ed.) Researching Teaching: Methodologies and Practices for Understanding Pedagogy. London: Routledge, 13-27.

Waring, M. \& Evans, C. (2015). Developing a critical approach to teaching and learning. London: Routledge.

Wells, G. (2002) Learning and teaching for understanding: The key role of collaborative knowledge building, in Jere Brophy (ed.) Social Constructivist Teaching: Affordances and Constraints: Advances in Research on Teaching, Volume 9. Emerald Group Publishing Limited, 1 - 41.

Whitehead, J. \& Clough, N. (2004). Pupils, the forgotten partners in education action zones. Journal of Education Policy 19 (2), 215-227.

Woolner, P., Clark, J., Hall, E. et al. (2010). Pictures are necessary but not sufficient: using a range of visual methods to engage users about school design. Learning Environments Research 13(1), 1-22.

Woolner, P., Clark, J., Laing, K. et al. (2012). Changing spaces: preparing students and teachers for a new learning environment. Children, Youth and Environments 22(1), 52-74.

Woolner, P., Clark, J., Laing, K. et al. (2014) A school tries to change: how leaders and teachers understand changes to space and practices in a UK secondary school. Improving Schools 17(2), 148-162. 